Research, part of a Special Feature on Navigating Trade-offs: Working for Conservation and Development Outcomes

\title{
Integrating Conservation and Development in the Peruvian Amazon
}

\author{
$\underline{\text { Catherine Kilbane Gockel }}^{1,2}$ and Leslie C. Gray ${ }^{2}$
}

\begin{abstract}
Recent studies have critiqued integrated conservation and development projects for failing to attain either of their two major goals. This paper evaluates one such project in Peru's Pacaya Samiria National Reserve, which entailed community-based natural resource-management plans for palm and aquatic resources. We conducted semistructured interviews with reserve inhabitants $(n=57)$ during May 2007, as well as key-informant interviews with state and non-governmental organization (NGO) staff. Monitoring data and reports from NGOs were important secondary sources in this study. The intervention has improved the status of targeted species and has improved the well-being of participants. This project worked well for a number of reasons, including the long-term commitment of the implementing organization, the social capital and legitimacy provided by participation in management groups, and the fact that local knowledge was incorporated into resource-management techniques.
\end{abstract}

Key Words: Amazonia; community-based natural resource management; integrated conservation and development; Ribereños; tropical-forest conservation.

\section{INTRODUCTION}

Tropical forest conservation has historically exhibited a "fortress conservation" or "fences and fines" mentality that has pitted people against the environment (Leader-Williams and Albon 1988, Rolston 1995, Adams and Hulme 2001, Redford et al. 2006, Siurua 2006, Chan et al. 2007). Before the 1980 s, it was not uncommon for local or indigenous peoples to be expelled from protected areas (Schwartzman et al. 2000). However, more recently, attempts to exclude humans from protected areas have been widely viewed as failures and, in many cases, these attempts are viewed to be ethically problematic, misanthropic, or simply inappropriate for the needs of developing countries (Wood 1995, Adams and Hulme 2001, Redford et al. 2006). Despite these changing views, evictions will likely continue as conservationists deal with the millions of impending displacements of "illegal" occupiers on strictly protected areas (Brockington et al. 2006). These failings, combined with local resistance to exclusionary policies, as well as the recognition that local peoples have often relied on parks, have led to a rethinking of conservation policy (Chapin 2004, West and Brockington 2006). Efforts to reconcile biodiversity conservation with human needs have since appeared under the umbrella of various programmatic interventions, ranging from integrated conservation and development projects to broader community-based conservation projects that have been less tied to protected areas (Agrawal and Gibson 1999, Hulme and Murphee 2001, Adams et al. 2004, Wilkie et al. 2006). Many of these programs have assumed that there had to be buy-in from local populations, and in order for that to happen, local populations had to receive economic benefits from their conservation actions.

The integrated conservation and development project (ICDP) approach became particularly popular for working with communities in or around protected areas. These projects were funded by both international conservation and development organizations and were viewed as a way to incorporate models of sustainable development into conservation (McShane and Wells 2004). Before long, they were viewed as the foremost site-specific approach to conserving biodiversity. This happened despite a lack of evidence about their effectiveness (Wells et al. 2004). 
In recent years, projects that have attempted to assimilate both conservation and development have been widely criticized (Oates 1999, Wunder 2001, Wilshusen et al. 2002, Christensen 2004, Terborgh 2004). A primary criticism has been that projects have failed to achieve either goal (Brown 2003). There has been little evidence that improving the economic well-being of people around protected areas will translate into conservation (Emerton 2001, McShane and Wells 2004). Critiques have also centered on the fact that projects were generally externally imposed, representing the ideas and agendas of outside conservation organizations. Projects tended to give local inhabitants little actual access to, or control over, natural resources (Chapin 2004, Kaimowitz and Sheil 2007). In their thorough review of Indonesian ICDPs, Wells et al. (1999) conclude that almost none could realistically claim to have enhanced biodiversity conservation. The ICDP in Ruteng Nature Recreation Park and Siberut National Park, for example, had a U.S.\$40 million budget but failed to generate significant conservation or livelihood benefits. Not only did the project have insufficient staffing and unrealistic institutional arrangements, but it also lacked a rational plan to address threats to the parks. It has been pointed out that the ICDP model seems to have become just another "expensive failure" (Wells et al. 1999).

Although it is doubtful that tropical forest conservation will return to the "fortress model" of past efforts, there is a vigorous debate about whether conservation policy should be concerned with development (Wilshusen et al. 2002, Brown 2003, Sanderson and Redford 2003, Adams et al. 2004, Roe and Elliott 2004). Some see conservation as the main goal and poverty alleviation as an afterthought (Sanderson and Redford 2004), whereas others argue that separating parks from people is a false dichotomy (West and Brockington 2006). Because many of the most threatened areas in tropical regions are inhabited by poor people dependent on natural resources, conservation policy must take them into account (Cordeiro et al. 2007, de Sherbinin 2008, Upton et al. 2008). Although the use of terms such as "integrated conservation and development" may have fallen out of favor, many interventions do, and will continue to, consider the well-being of populations inhabiting and surrounding protected areas (Wells et al. 2004).

We analyze an ICDP in the Pacaya Samiria National Reserve (PSNR), a flooded forest in the Peruvian
Amazon. This ICDP aimed to improve the wellbeing of local inhabitants and to sustainably manage the reserve's natural resources (ProNaturaleza et al. 1997). The ICDP received funding from The Nature Conservancy and USAID's Parks in Peril program, as well as the Tropical Forest Conservation Act debt-for-nature swap between the U.S. and Peru. The project began in 1991 and was implemented by the Peruvian NGO ProNaturaleza (the Peruvian Foundation for Nature Conservation). ProNaturaleza received approximately U.S.\$2.2 million through The Nature Conservancy and its donors for work in the PSNR. The intervention was known simply as "the ProNaturaleza project" in the field. The project worked with villagers to create resourcemanagement plans for paiche (Arapiama gigas) and arawana (Osteoglossum bicirrhosum) fish, sidenecked turtles (Podocnemis unifilis), and several species of palm. The PSNR's first management group began work in 1994. Management plans for paiche were approved in 2004, and arawana and turtle management plans followed in 2005 and 2006 respectively. We examine local perceptions of the effectiveness of management groups in improving livelihoods and increasing the numbers of key species. Locals generally perceived, and monitoring generally confirmed, that the status of key species had improved. This, in turn, led project participants to voice their beliefs that there were direct livelihood benefits of the project. We then review lessons learned from this project, in an effort to shed further light on the ICDP approach.

\section{STUDY AREA AND METHODS}

\section{Study Area}

The PSNR is a seasonally flooded palm and arboreal forest located in northeastern Peru at the confluence of the Amazon River. The 2080000 ha protected area was established in 1940 to protect paiche fish. It became a national reserve in 1982 (Instituto Nacional de Recursos Naturales (INRENA) 2000). The PSNR is an area of high biodiversity and is home to manatees (Trichechus inunguis), giant river otters (Pteronura brasiliensis), pink freshwater dolphins (Inia geogrensis), and tapirs (Tapirus terrestris) (INRENA 2000).

Widespread human migration into the Amazon has threatened the reserve's resources. Approximately 23930 people live within the PSNR in 106 distinct communities. Another 68117 people live in the 100 
communities in its buffer zone (INRENA 2008). Villagers reside legally within the reserve because their communities predate its creation. Although people are free to settle within existing communities, no new communities may be legally established within the PSNR (INRENA 1999). Some inhabitants have historical claims to land rights. Others are more recent migrants. According to Takasaki et al. (2001), land is held without title (by usufruct) and is transferred mainly along kin lines. On average, the villages in and around the PSNR have about 150 inhabitants (Noriega, personal communication, 2008). Reserve inhabitants, locally called Ribereños, are an ethnic mix of migrants from other Peruvian provinces with Cocama-Cocamilla indigenous peoples (Stocks 1983). The PSNR's Ribereños experienced an acculturation process in the last century, and although they acknowledge that they descend from "tribal" ancestors, they now consider themselves "Peruvian," as opposed to "indigenous" (Gow 2007). Several indigenous Cocoma-Cocamilla groups still live in the reserve (ProNaturaleza and Amazon Ivory EIRL 2005). Ribereños rely primarily on fishing and other aquatic extraction, agriculture, hunting, and gathering (INRENA 2000). Ribereños livelihoods are linked to the hydrologic phenomenon of high and low flood cycles that can rise and fall over a range of $10 \mathrm{~m}$. During the wet season, high river levels create new boat access points and it is difficult to prevent illegal extraction.

The only legal commercialization of resources in reserves like the PSNR is through approved and sustainable management plans (Government of Peru 2001). Subsistence fishing is permitted regardless of whether an inhabitant belongs to a management group. However, sustainable-use regulations were not being observed and the PSNR's natural resources were increasingly being depleted (Kvist and Nebel 2001). This is partly due to inadequate protection (Moreau and Coomes 2006). The reserve is too remote and too vast an area for the designated authority, INRENA, to be able to assert an effective state presence with its limited budget (Noriega, personal communication, 2008). Because of its size and location, and the threat to its unique ecology, the PSNR is a priority area for the World Bank, as well as many of the largest conservation groups in the world, including The Nature Conservancy and the Wildlife Conservation Society.

\section{Management Plans Prepared for the Park}

Management plans were developed on a permanagement group basis for specific species, with most plans needing years for biological monitoring and community buy-in. Management plans for moriche palms (Mauritia flexuosa), yarina palms (Phytelephas macrocarpa), and huasaí palms (Euterpe precatoria) addressed deleterious harvest practices. Villagers had traditionally harvested moriche palm forests by cutting down trees to reach fruits. ProNaturaleza provided groups with equipment and technical assistance to sustainably harvest fruits by climbing, rather than by felling moriche palms. Likewise, yarina groves surrounding local communities were depleted because villagers defoliated all the palm fronds on an individual tree, killing the palm. Under the yarina management plan, villagers left a sufficient number of fronds on the tree, enabling the tree's future survival, but still providing the resources needed for building houses. Management plans were also developed for huasaí palms. The stems of huasaí palms provide the raw materials for heart-of-palm, but the tree must be felled to remove it. The huasaí palm management plan prescribed that three trees be planted in place of every one felled.

For most residents of Pacaya Samiria, aquatic resources provide the principle economic activity and are the main food source. Overharvesting had put intense pressure on the reserve's fisheries, resulting in reduced catch sizes, diminished abundance of other species, and conflicts among fishermen for rights to certain areas (ProNaturaleza and Rios 2005).

Paiche are the largest freshwater fish in the Amazon. They are an important source of protein for local residents. Paiche have limited capacity for natural stock regeneration (ProNaturaleza et al. 2006). The fish was listed in CITES Appendix II in 1975 due to overfishing. Illegal fishing (where outsiders enter the reserve to extract large quantities of paiche for market sale) has persisted, despite protection measures (ProNaturaleza et al. 2006). ProNaturaleza began working with the Yacu Tayta management group in 1991 to monitor paiche and to develop management techniques. The management plan provides for population monitoring, harvest techniques, microzoning, and protection of paiche populations from poachers. The plan's quota allows up to $10 \%$ of the population to be fished, and 
mandates that participants use large $(30.5 \mathrm{~cm})$ mesh nets to reduce bycatch.

Arawana are paternal mouthbrooding fish that have been exported from the Peruvian Amazon since the 1950s. Arawana fingerlings have become increasingly popular on the international aquarium fish market. The killing of adult males to collect fry for market-based trade was threatening wild populations (Moreau and Coomes 2006).

Side-necked river turtles (Taricaya) and their eggs are a major source of local income and protein in villagers' diets. These turtle populations had declined due to illegal egg extraction and overhunting, and are now listed in CITES Appendix II. ProNaturaleza has worked with villagers since 1994 to develop management plans under which participants gather turtle eggs from nests on exposed sandy beaches and relocate them to artificial nests near the communities. Participants monitor the eggs, keeping watch to protect them from illegal extractors and predators. Turtle management plans have also been integrated into hands-on environmental education projects in local schools (ProNaturaleza 2006).

\section{Methods}

Semistructured interviews were conducted with Ribereños in villages in the PSNR during May 2007. We do not present a random sample of the reserve's many villages, nor of households within these villages. Instead, we selected villages from the Yanayacu Pucate basin, where ProNaturaleza has concentrated its efforts. Approximately $80 \%$ of the heads of households in this area participate in a management group. Each household in the four villages was visited and every available inhabitant was interviewed. Additionally, two communal guard posts were visited. The study interviewed 44 members of management groups and 13 nonmembers, as well as three INRENA park rangers. Interviews included at least three members of each management group. Females comprised 18 of the 57 Ribereños interviewed. In addition, multiple key informant interviews were conducted with the chief of the PSNR and the superintendent of INRENA, as well as with staff of ProNaturaleza and The Nature Conservancy. Interviews were conducted in Spanish and responses were recorded by hand. Villagers were asked for their perceptions of the socioeconomic and ecological success of
ProNaturaleza projects (see Appendix 1). ProNaturaleza field staff facilitated visits to the villages. Ribereños were interviewed in their homes or communal guard posts, without the presence of ProNaturaleza or government officials. Respondents only commented on the resources that they had experience managing or personal knowledge about. Villager responses were coded by content analysis to identify general themes. Table 1 presents a list of the villages visited, the number of group members interviewed, and the management groups in each community. Villages had multiple management plans dealing with one or more resources. Throughout the PSNR, about $40 \%$ of heads of household were involved in management groups. Other important sources of information included biological monitoring data collected by ProNaturaleza and management groups, NGO and INRENA reports, and personal communications. The authors are independent of The Nature Conservancy and ProNaturaleza. This research was funded exclusively by The Fulbright Program and the Environmental Studies Institute at Santa Clara University.

We acknowledge several limitations to this research. The questionnaire used to guide the interviews only captured perceptions. The "success" of the project was therefore a matter of perception, as the questionnaire could not quantify by how much people's lives had improved. Also, local respondents might have had a strategic motive for overstating the project's success in order to prolong external benefits. Sampling was nonrandom and was limited due to site-specific limitations in each village. This paper draws on biological monitoring data, provided by ProNaturaleza and the Centro de Datos para la Conservación, that suggest recovery of targeted species. However, interpretations were limited because no data exist providing "before" or "after" trend comparisons or simultaneous trends in neighboring villages not subject to the influence of this project. The PSNR was a promising site for an ICDP because local people were inclined to work with an NGO to conserve their natural resources, and recovering wildlife populations did not threaten villager livelihoods. 
Table 1. Groups interviewed for study

\begin{tabular}{|c|c|c|c|c|}
\hline Village & Group & $\begin{array}{l}\text { No. of group } \\
\text { members } \\
\text { interviewed }\end{array}$ & $\begin{array}{l}\text { Total no. of } \\
\text { members in } \\
\text { management group }\end{array}$ & Resources managed \\
\hline Veinte de Enero & $\begin{array}{l}\text { Palm Management } \\
\text { Committee }\end{array}$ & 8 & 14 & Moriche, Yarina, Huasaí \\
\hline Veinte de Enero & $\begin{array}{l}12 \text { de Octubre Natural } \\
\text { Resource Management } \\
\text { Association }\end{array}$ & 4 & 46 & $\begin{array}{l}\text { Moriche, Yarina, Huasaí, Cedar, } \\
\text { Mahogany, Huacapona }\end{array}$ \\
\hline Veinte de Enero & Nonmembers & 2 & N/A & N/A \\
\hline Arequipa & $\begin{array}{l}\text { Natural Resource } \\
\text { Management } \\
\text { Organization }\end{array}$ & 6 & 16 & $\begin{array}{l}\text { Moriche, Huasaí, Side-necked } \\
\text { turtle }\end{array}$ \\
\hline Arequipa & Nonmembers & 1 & N/A & N/A \\
\hline Yarina & $\begin{array}{l}\text { Natural Resource } \\
\text { Management } \\
\text { Organization }\end{array}$ & 3 & 15 & $\begin{array}{l}\text { Moriche, Yarina, Huasaí, Side- } \\
\text { necked turtle }\end{array}$ \\
\hline Yarina & $\begin{array}{l}\text { Yarina Community } \\
\text { Fishing Unit }\end{array}$ & 5 & 14 & Arawana, Side-necked turtle \\
\hline Yarina & Nonmembers & 4 & N/A & N/A \\
\hline Manco Cápac & Yacu Tayta & 10 & 14 & $\begin{array}{l}\text { Paiche, Arawana, Side-necked } \\
\text { turtle }\end{array}$ \\
\hline Manco Cápac & $\begin{array}{l}\text { Los Tibes Community } \\
\text { Fishing Unit }\end{array}$ & 5 & 12 & Arawana, Side-necked turtle \\
\hline Manco Cápac & Los Lobitos & 3 & 13 & Arawana \\
\hline Manco Cápac & Nonmembers & 6 & N/A & N/A \\
\hline $\mathrm{N} / \mathrm{A}$ & INRENA staff & 5 & N/A & N/A \\
\hline N/A & ProNaturaleza staff & 6 & N/A & N/A \\
\hline
\end{tabular}

\section{RESULTS}

\section{Management Plans: Conservation Aspects}

Our interviews indicated that local inhabitants believe management plans have aided species recovery. These perceptions are supported by biological monitoring data collected by management group members under the supervision of ProNaturaleza. Inhabitants were asked: (1) if natural resources were recovering in the area surrounding their community, (2) how they knew resources were recovering, (3) if they thought the management plans were responsible for the recuperation, and (4) the reasoning behind their answers. Fifty-two of the 57 inhabitants interviewed $(91 \%)$ said management plans were effective in facilitating species recovery. Two people declined to respond. Three respondents felt that natural resources had not recuperated, citing illegal extraction and unexpectedly high river levels. Responses did not differ significantly between group members and the 13 nonmembers 
interviewed. All nonmembers reported that managed resources had recovered. Eleven of the 13 said the livelihoods of group members had improved because of the project.

All 57 respondents said moriche palms were present in greater quantities and many commented that they were growing closer to communities. The president of the Veinte de Enero palm management committee said, "Just 3 years ago there were no palms left near communities and now moriche swamps are getting closer each year because we are not cutting down the tree to harvest its fruits." All 18 villagers who had experience with the yarina and huasaí management plans said that there had been considerable recovery of the palms.

Over $75 \%$ of respondents said arawana levels had increased and that the management plan was working. One villager commented, "There didn't used to be arawana in Yarina. Now not only are there arawana, but they are increasing." Members of Yacu Tayta said that arawana were their economic backbone and that the revenue they produced kept the organization together during difficult financial periods. In regards to paiche, all but one person interviewed said the management plan was working well and that paiche were recovering, particularly in El Dorado Lake. However, paiche are still threatened, despite the fact that the groups patrol the area and have communal guard posts on the lakes. Numerous villagers said that paiche levels would have risen considerably if there had been less illegal extraction. Nevertheless, members of Yacu Tayta said that paiche are plentiful, considering the number of illegal extractors from outside the reserve coming in for commercial fishing.

Everyone interviewed was emphatic about the recovery of the side-necked turtle. The president of the Yarina resource-management organization estimated a $75 \%$ repopulation rate. Likewise, the president of the Yarina communal fishing unit explained that before the management plans, illegal extractors killed mother turtles, but that this rarely occurs now. The president of Yacu Tayta exclaimed that there are now so many side-necked turtles that they are "tripping over them." The leaders of both Yacu Tayta and the Yarina resource-management organization said that the side-necked turtle management plan had produced the best results.

Villager perceptions of resource improvement are supported by biological monitoring conducted as part of the project. In 2001, 891 sacks of moriche palm fruits (mean weight of sacks $=40 \mathrm{~kg}$ ) were commercialized in Veinte de Enero. In 2003, the village increased its moriche fruit commercialization to 978 sacks (Ísola, peronsal communication, 2007). Between 1997 and 2000, the four ProNaturaleza field stations in the reserve harvested 85000 arawana fry. Between 1997 and 2003, field stations increased their arawana harvest to 400000 fry (Ísola, personal communication, 2007). Paiche levels have risen in El Dorado Lake since ProNaturaleza began working with Yacu Tayta. The results of a 1994 population count in a section of $\mathrm{El}$ Dorado Lake reported only 10 paiche individuals. In 2001, the estimated population of paiche in $\mathrm{El}$ Dorado was 470. In 2002, authorities estimated 582 paiche individuals in El Dorado Lake, and 630 in 2003 (INRENA 2006). Paiche populations were estimated by monitoring the large bubbles emitted from the fish using linear transect methodology (ProNaturaleza et al. 2006). Yacu Tayta members commented that without a management plan, paiche would have long since been extirpated from El Dorado Lake.

Table 2 shows the trends in species recovery in the Yanayacu Pucate Basin, where management groups were supervised by ProNaturaleza between 1994 and 2005. Management groups collected eggs for re-nesting, protected them from poachers, monitored hatching turtles, and released recently hatched turtles into the wild. The total number of eggs collected for re-nesting and the total number of turtles released into the wild increased almost tenfold during the 1994-2005 period. Because participants relocated every nest they found, the fact that they encountered increasingly more sidenecked turtle nests is an indicator that side-necked turtle populations are on the rise. Within the Yanayacu Pucate Basin, group members harvested $58.6 \%$ of the total number of eggs they collected, and $94.3 \%$ of hatched live turtle young were successfully released into the wild. Between 1994 and 2005, 1.3 million side-necked turtle young were managed and released by groups working with ProNaturaleza. On average, management groups harvested $57.9 \%$ of the total number of eggs collected throughout the reserve (Centro de Datos para la Conservación 2006).

An important secondary benefit of the management plans is that other wild animal populations have also recovered. Numerous respondents indicated that they more frequently spot wild animals and see more 
Table 2. Side-necked turtle recovery in the Yanayacu Pucate basin, PSNR

\begin{tabular}{|c|c|c|c|c|c|}
\hline Year & $\begin{array}{l}\text { Total eggs } \\
\text { collected } \\
\text { for re-nesting }\end{array}$ & $\begin{array}{l}\text { Total nests } \\
\text { collected }\end{array}$ & $\begin{array}{l}\text { Number of eggs } \\
\text { harvested }\end{array}$ & $\begin{array}{l}\text { Live turtle young } \\
\text { hatched }\end{array}$ & $\begin{array}{l}\text { Total turtles } \\
\text { released into the wild }\end{array}$ \\
\hline 1994 & 9603 & 282 & 6778 & 2197 & 2154 \\
\hline 1995 & 25916 & 767 & 18202 & 5712 & 5512 \\
\hline 1996 & 44409 & 1340 & 23608 & 16357 & 15889 \\
\hline 1997 & 45559 & 1390 & 22213 & 18555 & 18349 \\
\hline 1998 & 56884 & 1754 & 32971 & 19943 & 19826 \\
\hline 1999 & 60264 & 1829 & 31497 & 25577 & 25418 \\
\hline 2000 & 48211 & 1438 & 19271 & 25247 & 25103 \\
\hline 2001 & 68528 & 2031 & 33961 & 26483 & 22689 \\
\hline 2002 & 71369 & 2129 & 37242 & 27153 & 24226 \\
\hline 2003 & 72770 & 2282 & 46443 & 19703 & 17159 \\
\hline 2004 & 82849 & No data available & 59923 & 17474 & 15095 \\
\hline 2005 & 95237 & 3344 & 67616 & 24224 & 24224 \\
\hline Total & 681599 & 19347 & 399725 & 228625 & 215644 \\
\hline
\end{tabular}

Source: Centro de Datos para le Conservación 2006.

each year. Monkeys, caiman, giant river otters, majaz, deer, tapirs, dolphins, and huanganos can be found closer to the communities. A Yarina group member commented that until recently, caiman and giant river otters were not found close to communities due to illegal hunting. Although a variety of factors might have led to the recovery of these other resources, allowing fish and turtle populations to recover may have increased the numbers of aquatic predator species. Better management of palm species led to thicker palm groves with more fruit-bearing trees that probably enhanced wildlife habitat near the villages. There have been no documented conflicts between humans and wildlife in the area because of resource recuperation, and villagers are pleased that they do not have to travel as far to hunt. Some have expressed concern about the increase in giant river otters because the mammals can break their fishing nets (Noriega, personal communication, 2008).

\section{Management Plans: Development Aspects}

The principal goals of each management plan included making sustainable-resource extraction economically viable, and improving the economic conditions of families involved. Participants received direct economic earnings from managed resources, and profits were divided equitably among members. Groups designated a few members to sell their products. 
In 2005, Yacu Tayta commercialized $2369 \mathrm{~kg}$ of paiche and obtained gross earnings of Peruvian Nuevos Soles (PEN) 111845 (approximately U.S. $\$ 3759$ ). Also in 2005, Yacu Tayta commercialized 15733 arawana fry, generating gross earnings of PEN 47199 (approximately U.S.\$15 000). The annual average income for paiche and arawana fishermen from the Yacu Tayta management group increased from PEN 1548 (approximately U.S. $\$ 515)$ in 2000 and 2001 to PEN 3800 (approximately U.S.\$1270) in 2003 and 2004 (Ísola, personal communication, 2007). The community of Yarina received gross earnings of PEN 70000 (approximately U.S.\$22 250) for yarina palms in the year 2005 (INRENA 2006).

Because they operated under approved management plans, participants were able to legally commercialize their products and work through legitimate channels. In contrast, non-group members only had the right to harvest subsistencelevel quantities of natural resources and were prohibited from extracting sensitive species like paiche, arawana, and side-necked turtles from the interior of the PSNR, as they were not following sustainable management plans. Residents who participated in approved management plans were able to develop formal ties to markets.

Most participants (84\%) said that working in a management group improved their quality of life. The remaining $16 \%$ cited illegal extraction as the main impediment to recovering managed resources. One non-group member commented that even people who were not involved acknowledged that participating in management groups had improved the quality of life of members and that resources were more plentiful. Management plans permitted group members to purchase commodities that they could not have previously purchased. Many individuals commented that more people now have freezers, radios, or televisions in their homes. Before ProNaturaleza, many villagers did not have the Peruvian national identification documents that are legally required for basic civic and administrative activities. As part of the project, the NGO handled paperwork with Peru's National Registry of Identity and Civil Status and provided financial support so that group members could obtain their national identification documents.

Villagers listed several other ways that management groups had improved their quality of life. Some mentioned that work went faster in teams and that together they were able to accomplish things they could have done alone. For example, four or five men and a minimum of two canoes were needed to capture a single paiche fish. Group members took multiple-day shifts in guard posts to protect natural resources from poachers. Respondents also commented that management groups worked for the common good and provided mutual support and a social-safety net. For instance, if a member fell ill or had an accident, groups assumed a large portion of the costs of the person's recovery. At the community level, management groups dedicated $2 \%$ of their profits toward community health or education infrastructure. According to the president of Veinte de Enero's palm management committee, working in management groups made villagers more responsible and increased their confidence and leadership abilities. The president of Yarina's communal fishing unit reported that now that they are organized into formal groups, they can request support because they are recognized by the government and institutions that give aid and invest in community organizations.

Another benefit is that natural resources are now closer to communities. Numerous villagers said that because of the management plans, they walk less and spend less time traveling in dugout canoes to reach their resources. The president of the palm tree management committee in Veinte de Enero commented that moriche palm tree swamps are now closer and produce more fruits in greater quantities.

Management groups seem to have reduced illegal resource extraction for market-based purposes. According to respondents in each village, before ProNaturaleza's intervention, the PSNR's natural resources were depleted and nonresidents preyed freely on its resources. The reserve is now perceived to be a safer place to live and work. Wives of group members in each community mentioned that now they do not worry about their husbands when they leave to fish. The president of Yacu Tayta stated that participants now have better relationships with the Peruvian government. Numerous respondents from each village said that life is less stressful because they are not waiting on the reserve's headquarters to give them permission to harvest resources and because park rangers no longer confiscate the fruits of their labor.

Participants reported that management groups had broadened the opportunities available to them. For example, Yacu Tayta served as a model that other 
communities followed (their paiche management plan was the first plan to be approved in Peru). Several Yacu Tayta members travelled to Italy and Brazil to share their experiences in paiche management with the international community. Educational opportunities for children also increased. Children of numerous management group members now study in Iquitos, the regional capital, and hope to go to college. Their parents said they would not have been able to educate their children without the support of the groups.

Villagers said that adhering to management plans contributed to recovering wildlife populations. This is significant, because visible wildlife is a tourist attraction. Our interviews indicated that tourism is a powerful incentive for local communities to conserve their resources, primarily because participants expect that tourism will improve their quality of life. ProNaturaleza is working with management groups, and with Green Life, an NGO, on the Rumbo al Dorado community-based sustainable ecotourism initiative with a consortium of villages and management groups. Respondents in every village said that protecting natural resources so that there will be wildlife for tourists is an important motivator. Although the socioeconomic benefits of ecotourism have been limited to date, participants in the PSNR are optimistic about the future of this endeavor.

\section{DISCUSSION}

\section{The ProNaturaleza Project: Lessons Learned and Potential Problems}

\section{NGO commitment}

Before its Pacaya Samiria project, the implementing NGO ProNaturaleza had spent significant time (dating back to 1991) collecting baseline biological data for natural resources and interviewing villagers. They launched the project with a good understanding of its context. Furthermore, ProNaturaleza had a long-term commitment to the places where it was working. It took time to instill conservation values, perform baseline species monitoring, and persuade groups to adhere to management plans long enough to see results. The president of Yacu Tayta explained that there were approximately three difficult years when communities were following management plans and abstaining from exploiting resources, but not yet seeing results. This is typical of sustainable-use projects (Bodmer and Lozano 2001). The project also provided legal assistance to governmental and nongovernmental stakeholder groups so that resource-management plan approval processes could move faster and group enthusiasm would not wane (The Nature Conservancy 2007). Strong NGO support and oversight were critical, given the many competing influences in the PSNR and the threat of illegal extractors. According to villagers and ProNaturaleza field staff, it was essential to have someone who groups knew and trusted to work through issues. Because ProNaturaleza had worked on the project for so long through an adaptive management approach, it had developed significant institutional knowledge. The efficiency, accountability, and charisma of the NGO staff were also important factors. Also, in contrast to other conservation projects in the reserve, project staff lived in communities and formed close relationships with locals. All of the 57 villagers interviewed, including nonmembers, said they appreciated (or would appreciate) a ProNaturaleza live-in field station in their community.

\section{Diversification of seasonal management activities}

A positive point of the project was that it took into account the seasonal nature of resource extraction. Management plans were designed with the intent of sustaining villager economic activities throughout the year, largely through information obtained from rural participatory-evaluation workshops. One of ProNaturaleza's main strategies was to diversify seasonal management activities so that resources would be available year round, rather than having long lean periods with no harvests (Noriega, personal communication, 2008).

\section{Biological monitoring}

The ProNaturaleza project has included biological monitoring since 1994. Few ICDPs include longterm monitoring, and even fewer are able to demonstrate positive contributions to wildlife conservation (Kremen et al. 1994). Due to practical limitations, most conservation project teams are not able to measure project outcomes, largely because it is difficult to measure conservation success without widespread standardized and cost-effective methods for defining and measuring progress over time and comparing projects in other contexts (Salafsky and Margoluis 1998). 


\section{Social capital and empowerment}

Because communities were so isolated, creating social capital and civil society institutions were especially important factors. Vigilantism was not a viable option. Nor was racing one's neighbor to harvest resources as fast as possible, which would have resulted in a tragedy of the commons. Rather, adhering to approved management plans gave participants a sense of legitimacy, protected their interests, and enabled them to work with large institutions and the Peruvian government. By legally commercializing their natural resources, engaging in ecotourism, and being given the means to obtain their national identification documents, participants became further incorporated into Peruvian society.

The project not only empowered participants economically, but it also provided psychological and social empowerment. When interviewed, community members mentioned enhanced selfesteem because of their participation in management groups. Similarly, resource-management and ecotourism initiatives have contributed to community cohesion because families and individuals are working together to build successful ventures (Scheyvens 1999).

No formal registry exists of village organizations prior to 1994, but villages had schools, sports clubs, and evangelical religious organizations (Noriega, personal communication, 2008). Beginning in 1994, ProNaturaleza partnered with INRENA and other state authorities to gradually approach the villages together, and begin coordinating with local authorities and developing rural participatoryevaluation workshops. Although villagers understood that overexploitation was causing their natural resources to decline, they did not have adequate social capital or technical expertise to take action in a meaningful way. Community organizations were weak and needed the logistics and capacity of an external institution to catalyze local-level change and to develop accurate biological monitoring techniques and protection systems (Noriega, personal communication, 2008; villager interviews).

\section{Villager participation}

The techniques required for management plans were basic and easy to replicate. To enable villagers to help with species monitoring and harvesting data (both crucial components of management plans), ProNaturaleza streamlined the process and made it as simple as possible. ProNaturaleza performed detailed site evaluations, primarily though rural participatory-evaluation workshops, to obtain baseline data to tailor management practices to the appropriate management sites. ProNaturaleza worked with villagers in these workshops to draw up maps and graphs of current and future resourceuse patterns. Villagers mapped communal fishing, hunting, and agricultural activities, and shared their perceptions about which resources were declining.

The rural participatory-evaluation workshops served to gain information from villagers (i.e., how and where they had traditionally performed their fishing, hunting, and farming), and to find ways to ground management plans in local technical knowledge (ProNaturaleza 2003). Because management plans were based on a combination of scientific and traditional ecological knowledge, they were accepted by villagers and were easily replicated in nearby communities. For example, the paiche plan incorporated local knowledge consisting of a monitoring method based on the large bubbles emitted from the fish, and linear transect reconnaissance. The side-necked turtle management plan combined local turtle egg-collection practices with scientific training on how to properly relocate eggs into artificial nests. The moriche palm management plan utilized traditional ecological knowledge to designate specific locations and criteria for selecting palms to harvest and incorporated tree-climbing techniques developed by contemporary foresters.

The intervention strengthened participatory mechanisms by establishing a management committee for the reserve. The management committee, created in 2000, facilitates the participation of local settlers, international and national organizations, the Peruvian government, and research institutions. More than 120 people participated in a meeting in March 2007. This is an impressive number, given the dearth of public participation before the project and the fact that some people traveled for days from remote villages in order to participate in the meeting. The existence of this formal outlet for participatory management bodes well for the continuation of the project, for a future time when there is no longer an NGO presence in the reserve (The Nature Conservancy 2007). 


\section{Individual vs. community involvement}

Because the project worked with community members in self-formed management groups, both self-interest and group solidarity played a part in participant decision making. It would be interesting to examine the role of wealth, as well as social networks and education, in the decision to participate in management groups. Takasaki et al. (2001) found a strong positive association between resource-use activities and household physicalwealth portfolios, as well as between physicalwealth holdings and total income levels, in both land-poor and land-rich villages in Pacaya Samiria.

Participation is often used as an indicator for measuring project success (Prokopy 2005, Classen et al. 2008). According to the literature, project implementers should incorporate all levels of decision making in participatory processes, including the household level. In contrast to this inclusionary vision of natural resource management, ProNaturaleza tended to work only with interested villagers in self-formed management groups. Although the NGO initially briefed all interested community members and invited them to join management groups, it did not continue working with uninterested villagers. Entrance into management groups was voluntary. Anyone willing to do the work and follow the rules was welcome to join. No one was excluded or prevented from joining. Many villagers participated at the beginning of the project, but only the truly committed remained in the groups. Experienced members of Yacu Tayta commented that participants often wanted fast results when they joined management groups, but that it was a long and slow process. They said that less-dedicated members left management groups because they required too much work or took up too much time. In this case, motivated individuals and dynamic households, as opposed to entire communities, took part in resource-management activities (Durand, personal communication, 2007).

Residents who (voluntarily) refrained from joining management groups were still considered full members of their respective communities. However, nonmembers were not allowed to extract paiche, arawana, or taricaya, nor were they permitted to extract other resources for commercialization or in quantities larger than for subsistence levels. INRENA only granted permission for commercial harvest to groups with approved management plans. Those entering from outside the reserve needed permission from an INRENA guard or their harvests could be confiscated. This has led to conflicts, as described below. To date, no studies exist about the economic levels of nonmembers (Noriega, personal communication, 2008). However, ProNaturaleza field staff observed that management group members tended to have higher levels of organization and invested capital, as well as acquisition of goods and property (Noriega, personal communication, 2008).

\section{Illegal extraction}

Not all aspects of the project have worked well, and participation in management groups was not without trade-offs. Members had to abstain from harvest during periods of resource recovery and spend weeks away from their families to perform protection activities. This sometimes entailed detaining or confiscating harvests from nonmembers (who were occasionally relatives or neighbors). This has created some tension between groups that followed approved management plans and people who did not. Although participants said protection activities helped create the conditions for species recovery, benefits were not confined to group members, and free-riding has been an issue. Yacu Tayta members complained that illegal extractors only became interested in harvesting from $\mathrm{El}$ Dorado Lake after management groups had recovered paiche.

Illegal extraction was problematic throughout the life of the project. Villagers commented that although natural resources were more abundant because of management plans, there would be significantly more resources were it not for external illegal extractors. Protecting managed resources from illegal extraction was difficult and often dangerous work. Protection activities consisted of the daily recording of information in a notebook and communicating via radio with park rangers. Group members manned guard posts at critical areas for days at a time, controlling access and making sure extractors had permission to harvest resources. Groups also supervised the tools and methods used to extract resources (such as the size of nets used to fish), as well as which resources were extracted and in what volume. Protection activities placed an economic burden on group members, including transportation and food costs while on the job, and the income they forwent while volunteering. The 
president of Yacu Tayta calculated the group spent PEN 228300 (approximately U.S.\$72 500) on resource protection over the course of a calendar year (allowing for three group members to work 12day rotations at El Dorado Lake and including food and transportation costs).

Even worse, illegal extractors from outside the reserve tended to enter in large groups and used violent methods if patrols attempted to curtail their activities. For example, the community of Arequipa had a confrontation with illegal loggers, where the loggers threatened to kill everyone in the management group. The villagers took them at their word and quickly fled the community, leaving only eight families in Arequipa. The community has only recently begun to rebuild itself.

Securing fair and reliable markets for managed resources

Another shortcoming of the project is that the implementing NGO was initially so focused on getting the management plans up and running that it did not secure a fair market with good prices for the managed resources at the beginning of the project. Unstable or low prices, as well as product quality and consistency, and the costs of transporting goods to market, are other issues that ProNaturaleza has had to turn its attention to. It acknowledges that instead of simply focusing on managing natural resources, it should have secured markets that give fair prices for the managed resources earlier on (Noriega, personal communication, 2008).

\section{CONCLUSION}

Over the long term, people profit from sustainable use of wildlife because the benefits of use continue (Freese 1997). The ProNaturaleza project connected livelihoods to conservation (Wells et al. 2004) and to food security, likely to be a primary driver of long-term rural participation (Classen et al. 2008). Our findings echo Peltenburg et al. (2000) and Day (2007) in that there should be long-term commitment by a local NGO to provide continuity of process, understand villager needs, and use local knowledge. Education, training, and provision of good-quality technical assistance are also critical, as is a serious attempt to undertake biological monitoring. However, the project is not an unmitigated success, mainly because of illegal extraction and the need for fair and reliable markets.
Making it economically beneficial and practical for people to conserve their resources may not be enough, but it is too early to abandon the strategy of combining conservation and development. Notwithstanding their rather disappointing record, no method has proven to be more effective than ICDPs at linking protected-area management with the interests of local people (McShane and Wells 2004). We hope that rather than moving on to the next "silver bullet," future project implementers might learn from the successes and pitfalls of this project to improve upon the ICDP approach.

Responses to this article can be read online at: http://www.ecologyandsociety.org/voll4/iss2/art11/ responses/

\section{Acknowledgments:}

We would like to thank INRENA and the Peruvian government for granting permission to carry out this study in the Pacaya Samiria National Reserve. Many thanks to ProNaturaleza and The Nature Conservancy, especially Sandra Ísola, Javier Noriega, and Felipe Vela Montalván, for logistical and field support, and to the Peruvian Fulbright Commission and Santa Clara University.

\section{LITERATURE CITED}

Adams, W. M., and D. Hulme. 2001. If community conservation is the answer in Africa, what is the question? Oryx 35(3): 193-200.

Adams, W. H., R. Aveling, D. Brockington, B. Dickson, J. Elliott, J. Hutton, D. Roe, B. Vira, and W. Wolmer. 2004. Biodiversity, conservation and the eradication of poverty. Science 306:11461149.

Agrawal, A., and C. C. Gibson. 1999. Enchantment and disenchantment: The role of community in natural resource conservation. World Development 27(4):629-649.

Bodmer, R. E., and E. P. Lozano. 2001. Rural development and sustainable wildlife use in Peru. Conservation Biology 15(4):1163-1170.

Brockington, D., J. Igoe, and K. Schmidt-Soltau. 
2006. Conservation, human rights, and poverty reduction. Conservation Biology 20(1): 250-252.

Brown, K. 2003. Integrating conservation and development: a case of institutional misfit. Frontiers in Ecology and the Environment. 1(9): 479-487.

Centro de Datos para la Conservación (CDCUNALM). 2006. Resultados preliminares de la sistematización del manejo de taricayas en la Reserva Nacional Pacaya Samiria (1994-2005). Lima, Peru.

Chan, K. M., R. M. Pringle, J. Ranganathan, C. L. Boggs, Y. L. Chan, P. R. Ehrlich, P. K. Haff, N. E. Heller, K. Al-Khafaji, and D. P. Macmynowski. 2007. When agendas collide: human welfare and biological conservation. Conservation Biology 21(1):59-68.

Chapin, M. 2004. A challenge to conservationists. World Watch 7(6).

Christensen, J. 2004. Win-win illusions. Over the past two decades, efforts to heal the rift between poor people and protected areas have foundered. So what next? Conservation in Practice 5(1):12-19.

Classen, L., S. Humphries, J. FitzSimons, S. Kaaria, J. Jiménez, F. Sierra, and O. Gallardo. 2008. Opening participatory spaces for the most marginal: learning from collective action in the Honduran hillsides. World Development 36 (11):2402-2420.

Cordeiro, N. J., N. D. Burgess, D. B. K. Dovie, B. A. Kaplin, A. J. Plumptre, and R. Marrs. 2007. Conservation in areas of high population density in sub-Saharan Africa. Biological Conservation 134 (2):155-163.

Day, C. 2007. Sustaining the turnaround: what capacity building means in practice. International Studies in EducationalAdministration 35(3):39-48.

de Sherbinin, A. 2008. Is poverty more acute near parks? An assessment of infant mortality rates around protected areas in developing countries. Oryx 42(1):26-35.

Emerton, L. 2001. The nature of benefits and the benefits of nature: why wildlife conservation has not economically benefited communities in Africa. Pages 208-226 in D. Hulme and M. Murphee, editors. African wildlife and livelihoods: the promise and performance of community conservation. James Currey, Oxford, UK.

Freese, C. H. 1997. The "use it or lose it" debate: issues of a conservation paradox. Pages 1-48 in C. H. Freese, editor. Harvesting wild species: implications for biodiversity conservation. Johns Hopkins University Press, Baltimore, Maryland, USA.

Government of Peru. 2001. Reglamento de la ley de áreas naturales protegidas. AG. Pub. D.S. No. 038-2001. 26 June 2001.

Gow, P. 2007. "Ex-Cocama:" transforming identities in Peruvian Amazonia. Pages 194-215 in C. Fausto and M. Heckenberger, editors. Time and memory in indigenous Amazonia. University Press of Florida, Gainesville, Florida, USA.

Hulme, D., and M. Murphee. 2001. The nature of benefits and the benefits of nature: why wildlife conservation has not economically benefited xommunities in Africa. African Wildlife and Livelihoods: the promise and performance of community conservation. James Currey, Oxford, UK.

Instituto Nacional de Recursos Naturales (INRENA). 1999. Plan director para las áreas naturales protegidas del Perú. Lima, Peru. .2000. Plan maestro de la Reserva Nacional
Pacaya Samiria. INRENA, Lima, Peru.

2006. Proceso de involucramiento de pobladores locales en conservación y manejo de recursos naturales y turismo dentro de la Reserva Nacional Pacaya Samiria. INRENA, Lima, Peru.

.2008. Plan maestro de la Reserva Nacional Pacaya Samiria. INRENA, Lima, Peru.

Kaimowitz, D., and D. Sheil. 2007. Conserving what and for whom? Why conservation should help meet basic human needs in the tropics. Biotropica 39(5):567-574.

Kremen, C., A. M. Merenlender, and D. D. Murphy. 1994. Ecological monitoring: a vital need for integrated conservation and development programs in the tropics. Conservation Biology 8 (2):388-397. 
Kvist, L. P., and G. Nebel. 2001. A review of Peruvian flood plain forests: ecosystems, inhabitants and resource use. Forest Ecology and Management 150(1-2):3-26.

Leader-Williams, N., and S. D. Albon. 1988. Allocation of resources for conservation. Nature 336:353.

McShane, T. O., and M. P. Wells. 2004. Getting biodiversity projects to work: towards more effective conservation and development. Columbia University Press, New York, New York, USA.

Moreau, M. A., and O. T. Coomes. 2006. Potential threat of the international aquarium fish trade to silver arawana Osteoglossum bicirrhosum in the Peruvian Amazon. Oryx 40(2):152-160.

Oates, J. F. 1999. Myth and reality in the rainforest: how conservation strategies are failing in West Africa. University of California Press, Berkeley, California, USA.

Peltenburg, M., J. d. Wit, and F. Davidson. 2000. Capacity building for urban management: learning from recent experiences. Habitat International 24 (4):363-373.

Prokopy, L. S. 2005. The relationship between participation and project outcomes: evidence from rural water supply: projects in India. World Development 33(11):1801-1819.

ProNaturaleza. 2003. Taller de evaluación rural participativa TERP San Carlos, 26-29March 2003. Workshop report. ProNaturaleza, Iquitos, Peru.

ProNaturaleza. 2006. Análisis del plan de manejo para el aprovechamiento de "taricaya" (Podocnemis unifilis) en la cuenca del Yanayacu-Pucate, Reserva Nacional Pacaya Samiria. ProNaturaleza, Iquitos, Peru.

ProNaturaleza, and Amazon Ivory EIRL. 2005. Plan de manejo de Phytelephas macrocarpa "yarina" en el area de influencia de la comunidad de Veinte de Enero Cuenca Yanayacu Pucate. ProNaturaleza, Iquitos, Peru.

ProNaturaleza, and Rios, G. R. 2005. Plan de manejo de alevinos de Osteoglussum bicirrhosum "arawana" en la cocha El Dorado - Reserva Nacional Pacaya Samiria. Organización de Pescadores y Procesadores Artesanales (OSPPA)
Yacu Tayta. ProNaturaleza, Iquitos, Peru.

ProNaturaleza, Rios, G. R., Noriega, N., and OSPPA-UPC Yacu Tayta. 2006. Plan de manejo de Arapaima gigas "paiche" en la cocha el Dorado, Cuenca Yanayacu Pucate-RNPS. ProNaturaleza, Iquitos, Peru.

ProNaturaleza, The Nature Conservancy, and USAID. 1997. Informe final de ejecución, resultados y logros del proyecto: 'empleo y uso sostenible de recursos en la Reserva Nacional Pacaya-Samiria.' ProNaturaleza, Iquitos, Peru.

Redford, K. H., J. G. Robinson, and W. M. Adams. 2006. Parks as shibboleths. Conservation Biology 20(1):1-2.

Roe, D. and Elliott, J. 2004. Poverty reduction and biodiversity conservation: rebuilding the bridges. Oryx 38(2): 137-139.

Rolston, H. I. 1995. Duties to endangered species. Pages 60-75 in R. Elliott, editor. Environmental Ethics. Oxford University Press, Oxford, UK.

Salafsky, N., and R. Margoluis. 1998. Threat reduction assessment: a practical and cost-effective approach to evaluating conservation and development projects. Conservation Biology 13(4):830-841.

Sanderson, S., and K. Redford. 2003. Contested relationships between biodiversity conservation and poverty alleviation. Oryx 37(4):389-390.

Sanderson, S., and K. Redford. 2004. The defence of conservation is not an attack on the poor. Oryx 38(2):146-147.

Scheyvens, R. 1999. Case study: ecotourism and the empowerment of local communities. Tourism Management 20(2):245-249.

Schwartzman, S., D. Nepstad, and A. Moreira. 2000. Arguing tropical forest conservation: people versus parks. Conservation Biology 14(5):1370 1374.

Siurua, H. 2006. Nature above people: Rolston and "fortress" conservation in the south. Ethics and the Environment 11(1):71-76.

Stocks, A. 1983. Native enclaves in the Upper Amazon: a case of regional non-integration. Ethnohistory 30(2):77-92. 
Takasaki, Y., B. L. Barham, and O. T. Coomes. 2001. Amazonian peasants, rainforest use, and income generation: the role of wealth and geographical factors. Society and Natural Resources 14(4):291-308.

Terborgh, J. 2004. Requiem for nature. Island Press, Washington, D.C., USA.

The Nature Conservancy. 2007. Pacaya Samiria National Reserve, Peru: parks in peril end-ofproject report. Washington, D.C., USA. [online] URL: http://www.parksinperil.org

Upton, C., R. Ladle, D. Hulme, T. Jiang, D. Brockington, and W. M. Adams. 2008. Are poverty and protected area establishment linked at a national scale? Oryx 42(1):19-25.

Wells, M., S. Guggenheim, A. Khan, W. Wardojo, and P. Jepson. 1999. Investing in biodiversity: a review of Indonesia's Integrated Conservation and Development Projects. The World Bank, Washington, D.C., USA.

Wells, M.P., T. O. McShane, H. T. Dublin, S. O'Connor, and K. H. Redford. 2004. The future of Integrated Conservation and Development Projects: building on what works. Pages 397-422 in T. O. McShane, and M. P. Wells, editors. Getting biodiversity projects to work: towards more effective conservation and development. Columbia University Press, New York, New York, USA.

West, P., and D. Brockington. 2006. An anthropological perspective on some unexpected consequences of protected areas. Conservation Biology 20(3):609-616.

Wilshusen, P. R., S. R. Brechin, C. L. Fortwangler, and P. C. West. 2002. Reinventing a square wheel: critique of a resurgent "protection paradigm" in international biodiversity conservation. Society and Natural Resources 15(1):17-40.

Wilkie, D. S., G. A. Morelli, J. Demmer, M. Starkey, P. Telfer, and M. Steil. 2006. Parks and people: assessing the human welfare effects of establishing protected areas for biodiversity conservation. Conservation Biology 20(1): 247249.
Wood, D. 1995. Conserved to death: are tropical forests being over-protected from people? Land Use Policy 12(2):115-135.

Wunder, S. 2001. Poverty alleviation and tropical forests-what scope for synergies? World Development 29(11):1817-1833. 


\section{Appendix 1. Interview Instrument (Translated from Spanish)}

\section{Please click here to download file 'appendix1.pdf'.}

